\title{
Lobbies: The Hidden Side of Digital Politics
}

\author{
Antonio Castillo-Esparcia, Ana Almansa-Martinez, \\ and Gisela Gonçalves
}

\begin{abstract}
1 INTRODUCTION
Contemporary societies, characterized by their complexity, are shaped by numerous social interests that must be present in the political system (Almond, 1958; Burdeau, 1982). These interests are the expression of citizens' demands on public affairs, which must be addressed by those in power (Bentley, 1983; Berry, 1977). These are also translated into the political system through specialized organizations, which traditionally have consisted of political parties. But interests are also conveyed through lobbies, in the form of organizations that develop activities aimed at public authorities in order to influence decisions that affect their interests.
\end{abstract}

\footnotetext{
A. Castillo-Esparcia $(\bowtie) \bullet A$ A. Almansa-Martínez

University of Málaga, Málaga, Spain

e-mail: acastilloe@uma.es; anaalmansa@uma.es

G. Gonçalves

University of Beira Interior, Covilhã, Portugal

e-mail: gisela.goncalves@labcom.ubi.pt

(C) The Author(s), under exclusive license to Springer Nature

Switzerland AG 2022

B. García-Orosa (ed.), Digital Political Communication Strategies, The Palgrave Macmillan Series in International Political

Communication, https://doi.org/10.1007/978-3-030-81568-4_5
} 
In any social organization, pressure groups appear as an inseparable element of the political structure with a representation in the long and complex process of forming decisions, either by integrating the demands or by setting the hierarchy and the order of propositions or requests, which may be addressed in the political dialogue.

The starting point for the analysis of social groups and political life was the research conducted by Bentley, in his study of the different social manifestations. Thus, it included his famous statement that implies recognition of the significance of associations in contemporary societies:

The main work while studying all forms of social life is the analysis of the groups, which can be classified in multiple manners. If only groups are defined properly, everything is already set. And when I say everything, I mean each and every one of the things. (1983: 256)

Regarding the concept of lobbying, the Venice Commission defines it as "the oral or written communication by private individuals or groups, each with varying and specific interests, with a public official to influence legislation, policy or administrative decisions" (CDL-AD, 2013.011-eReport on the Role of Extra-Institutional Actors in the Democratic System -Lobbying-. Adopted by the Venice Commission at its 94th Plenary Session, Venice, 8-9 March 2013).

The UK Parliament defines the lobby as "when an individual or a group tries to persuade someone in Parliament to support a particular policy or campaign. Lobbying can be done in person, by sending letters and emails or via social media".

For its part, the European Union, through its Transparency Register, defines lobbying as "any activity with the aim of directly or indirectly influencing the formulation or implementation of policies and decision-making processes".

\section{Features of Lobbying}

The key issues that a lobbyist must address have changed over time. This mutation directly relates to the exchange of techniques used by these agents of mediation. The so-called old lobby has been joined by the new lobby. While the former refers to bribery, corruption, etc., the latter emphasizes the action performed on public opinion. Nowadays, this shift has enabled "instrumental lobbyist", who besides being an expert in direct 
techniques of influencing public decision-makers, must also be knowledgeable in training or education of the public.

Routes of origin for professional lobbyists are diverse: a former Member of Parliament or Government, which has close relations to it, as the main shareholder or beneficiary, with private interests, employees of firms or managers of private associations, as well as advertising and public relations specialists, and lastly journalists.

However, experts point to different backgrounds for lobbyists (e.g., lawyers or PR firms), such as Berry (1989: 91-93), who emphasizes law firms and public relations offices. By contrast, Hrebenar and Scott (1990: 71-88) added former congressmen and members of the administration. Another source of lobbyists is through outgoing high-level government officials, who become part of business management or lawyer firms (the revolving door concept).

Good lobbyists should be able to run and demonstrate a range of features to complete their activity satisfactorily. All these actions and activities can be summarized in ten points, which express the main features of the job:

1. They must know how to advise, inspire, prepare, and coordinate the activities of organizations that represent groups in the different branches of government (legislative, executive, and judicial), as well as public-focused actions.

2. The relationship between the people who achieve the goals at work should be deep, friendly, private, and fruitful, especially with key players. They also must have a wide network of contacts at the highest levels.

3. The contacts that they maintain should be enabled throughout their activities in order to get quick and easy access.

4. They should be aware of and be able to communicate the views of supporters in the various processes at the most appropriate time, timely and accurately prepare more appropriate judgments, and get positively highlighted circumstances. They must always resort to the truth, because if the data and arguments are not valid, any further action will be doomed to failure.

5. They must be aware at all times and promptly apply judicious techniques as well as be ready to come up with, in any case, the optimal and appropriate solution. 
6. They must be able to inspire and even produce a large number of petitions, letters, and messages that could reach public decisionmakers, as well as being able to define the best moment to act (grassroots lobbying).

7. They should possess sufficient scholar knowledge to define appropriate advice on the amount and type of pressure exerted on a given political actor.

8. Their knowledge of public relations techniques, information, and advertising should be maximized in order to improve the image of supporters constituents. They must have easy access to means of communication that enable the publication of information favorable to most of the represented interests.

9. They should be inspiring for publications and information to lean toward the political actor they are lobbying for in the political process.

10. They should have the appropriate training and expert knowledge in organizing conferences, visits, and so on, of public figures and stakeholders, in order to obtain more information about them.

\section{Lobbying and Political Action}

A dual phenomenon is taking place, namely the stateisation of society and the socialization of the state, both elements that interact in a reciprocal manner. Thus, there is a growing presence of public authorities in the resolution of social issues and conflicts. Likewise, the state and its powers increasingly rely on the opinions of social organizations in order to be able to develop regulations as closely as possible to the social reality (Chalmers \& Macedo, 2020; De Bruycker \& Beyers, 2019).

Hence, many analysts point to a direct relationship between the increase in state participation in society and the growing presence of lobbies in public institutions (Grant, 1989; Gray \& Lowery, 1993; McFarland, 1987). In this sense, Almond and Powell (1972: 19) pointed out the need to attribute greater complexity to the traditional model of public powers (legislative, executive, and judicial), adding other functions such as the articulation of interests and the aggregation of interests. For Easton (1965: 116), lobbies, like political parties, act as structural regulators on the volume of demands by selecting and modulating the numerous social demands that are addressed to the public authorities. This synthesis and 
homogenization make it possible to regulate the quantity of demands, rendering them acceptable in the eyes of the system.

The techniques used by lobbyists have been systematized by Ziegler and Dye (1990: 227-230) into four categories:

(a) Access to power, to communicate relevant information to public decision-makers. A fundamental requirement is to have open access to the political system. Law firms, PR, and consulting agencies offer connections and potential clients, thus becoming real companies that carry out lobbying activities without being considered de jure but de facto.

(b) Information. A good lobbyist knows the legislative process, is an expert in political debate, and provides information about the group's position in different situations. In order to be able to do their job, they have to know how to use the right language, know the relevant people, know how to deal with different issues, and so on.

(c) Grassroots mobilization through letters, messages, or phone calls from citizens to the relevant people, always under the appearance of being spontaneous.

(d) Grassroots support campaigns for all of the above actions and on all issues. This support is carried out with the intention of creating a public image favorable to groups or individuals or to create a concrete public demand.

For interest groups, it is essential to take part in public policy processes, although not all have the same capacity for access and action due to various factors (Gallagher Cunningham et al., 2017 and Klüver, 2013). If we look at this imbalance of lobbying forces, a series of values can be shown that strengthen these capabilities for political influence, such as:

(a) The ability to mobilize lobby supporters or members as a sign of social support in the context of public opinion, which has a relevant value in the democratic system. Thus, there are interest groups that mobilize their members through public demonstrations, support in the form of messages in different formats, explaining the number of followers or valuing the economic volume generated in the sector, among other things (Branton et al., 2015; Mergeai \& Gilain, 2020; Rasmussen et al., 2018). 
(b) The lobby's financial capacity allows it to carry out a set of activities that cannot be carried out by lobbies with scarce economic resources. Hence, business or employers' lobbies have greater resources than those that generate income from the volume of their membership, such as NGOs, consumer associations, professional associations, or trade unions. These resources, in turn, can be projected onto other capacities available to lobbies (Carty, 2010; Dempsey, 2009; Dür, 2008; Schnakenberg, 2017).

(c) Access to public authorities is essential to be able to engage in dialogue processes with decision-makers, as it is difficult to gain the support for a proposal just by handing over documentation or through grassroots campaigns. This capacity is part of the revolving door concept, since those who have been part of the public authorities maintain a network of contacts that allows them to interact more easily. Likewise, being aware of the gatekeepers in the administration or the legislature is essential to know who to act on, a responsibility that does not necessarily fall on the person with the highest hierarchical rank (Dür et al., 2015).

(d) Advocacy helps when there is a fit with social values, since it is easier for those in power to make decisions with social demands in line with what is acceptable to the population as a whole (Biliouri, 1999; Rasmussen et al., 2018).

(e) Having a favorable social image facilitates the lobby's work, as its proposals seem to have a higher level of legitimacy (Klüver et al., 2015; Lowery, 2013; Marshall, 2015; Rasmussen, 2015).

(f) Occupying a strategic space in society or in the economy also confers greater weight in dialogue processes. This would be the case of the role of the financial system in the economic system, which is realized in an expression widely used in European institutions, as "systemic elements", that is, underpinning the system.

In essence, lobbying is linked to the political culture of each society and is a reflection, to a certain extent, of its ability to structure and manage social demands toward the political system. Furthermore, based on the political organization in which the lobby carries out its activity, it is possible to plan activities and actions to influence different institutional players, such as: 
(a) The government, since this is the institution with the initiative to propose legislation, because it has a considerable administrative structure and information

(b) The Parliament, because it is the body in which laws are discussed and approved, so lobbies must participate in the whole political process

(c) The judiciary, as it is the body that oversees the legality of regulations and is an area in which lobbies have an influence

(d) Political parties, as they are organizations that play a fundamental role in the political process

These actors are aware of how they can be influenced by lobbyists. Which of them acts on the other is something that depends on the organizational, legislative, cultural, and social contexts, so each lobbyist must be aware of these balances of power and influence those that are most operational and effective.

\section{LobBying AND Communication}

In its modern form, the political game is increasingly organized and structured, both by public opinion and by symbolic political struggle. The latter tends to cut down, significantly, to a public opinion battle. As the representatives of public opinion and advocates for society's claims, lobbyists seek to capture the intentions of the public in order to report them to public authorities.

One of the key points of political domination is based on the mainly symbolic mechanisms, since the most important political action is shown surreptitiously and overlappingly, as well as it mostly consists of the enforcement of the world rating systems.

This symbolic structuring has an impact on individual and collective ideologies and, specifically, on journalists and their companies, as entities that interact in a given social system, and therefore cannot be removed from it. In this sense, the abovementioned system influences perceptions and thoughts of individuals, including media professionals.

The communication flow that is established from the societal system toward political bodies has been defined by Meynaud (1962: 116-118) as the action carried out by pressure groups, which collect the information circulating in society and transmit it to political decision-makers. In this way, they integrate the aspirations of individuals who, without these 
organizations, would not have formal channels, political parties excluded, with dangerous consequences in the form of disorderly and violent petitions.

For a lobby, the communication strategy could focus on two different perspectives:

1. Proactive strategy, in which the lobby takes the initiative in the definition, elaboration, and approval of public policies, which allows it to raise flags and anticipate issues that may affect the interest group. Being able to raise issues that may affect the interests of the lobby facilitates the structuring of the issue, sets the conceptual boundaries of the discussion, and influences the approach to the solution (Carty, 2010; De Bruycker, 2016; Schnakenberg, 2017).

2. Reactive strategy, which is established through a passive action of the lobby, which is only put into action when a decision affecting the lobby's interests is being considered, discussed, or approved. This action does not allow solutions to be proposed, but it is based on defensive activity, which greatly reduces the lobby's scope for action (Chari \& Hillebrand O’Donovan, 2011 and Rasmussen et al., 2018).

Currently, one of the most significant resources is actions on public opinion (grassroots mobilization). This technique has been widely studied in American political science, particularly since the emergence of the socalled new lobbying, as reflected in studies by Fowler and Shaiko (1987), and Whiteley and Winyard (1987). The set of strategies aimed at public opinion is structured into a series of functions:

1. To diffuse its deprecations, proposals, and demands over the citizens as a whole (diffusion function).

2. Mobilizing aspect on its adherents and supporters (mobilizing function).

3. Psychological variant in relation to its members, providing an image of psychological support. Thus, in a society of increasingly isolated individuals, the group followers have the image of belonging to an association that has a social presence, with the colligations manifesting themselves as welcoming instances for individuals (psychic cohesion function). 
When we talk about the actions of lobbies, it is necessary to appeal to the strong presence of communication in their actions, because relations with public authorities involve information supply, the presence of deliberative bodies, and personal relations with those who participate in the process of discussing public policies. From the lobbies' perspective, their strategies fall into two main types: direct access to decision-makers (direct lobbying) or the creation of social mobilization campaigns in support of their demands (indirect lobbying).

Direct lobbying, understood as direct communication with politicians and public officials (either within or outside institutional premises) and which can take the form of:

1. Advice or presentations to officials, either on an ad hoc or on periodic basis

2. Providing draft reports to civil servants in which specific details of the policy itself are drafted

3. Seeking informal contacts with individual politicians or branches of civil society, including having simple telephone conversations with such staff

4. Formal or invited consultation through institutionalized channels

5. Participation in hearings, such as parliamentary committees

6. Participation in a delegation or conference

7. Requested, or unsolicited, information or documents sent to politicians and civil servants

Indirect or grassroots lobbying is one of the current trends in public affairs, in which a set of communication actions are produced on the political leader or officials, through presence in the media, by direct requests from citizens or by creating social media spaces. In its most benign form, this type of citizen participation can be enriching for citizens. However, this technique can also be more reprehensible when it becomes astroturfing, the controversial practice of lobbyists hiding behind front organizations to give the appearance of popular support for a cause that is in fact funded by private interests. The activities associated with these offline and online campaigns are as follows:

1. Direct online citizens' petitions

2. Letters to government or parliamentarians

3. Public debates

4. Leaflets and posters 
5. Demonstrations, among other activities, in order to put pressure on politicians to listen to them

6. Use of related organizations such as advocacy associations

7. Use of other entities such as think tanks

8. Blogging

9. Cyber activists posting on social media

One of the essential aspects of lobbies in their public opinion-shaping activity is to present themselves to those in power as defenders of socially relevant demands and with the need to adopt political solutions. However, it should not be forgotten that it is necessary to perform audience management, as lobbying, being a communicative activity, must be aware of the channels and sources of information of those who must make the decision. In this sense, the results of the FleishmanHillard consultancy firm on the main information channels of European parliamentarians are relevant (Graph 5.1).

It is striking that search engines and online newspapers, along with European media and social media conversations are the most frequently used tools. In contrast, blogs and stakeholder websites, together with Wikipedia and stakeholder social media, are the least frequently used.

\section{SEARCH ENGINES, NEWSPAPERS, AND EU AND SOCIAL MEDIA ESSENTIAL TO LEGISLATIVE WORK}
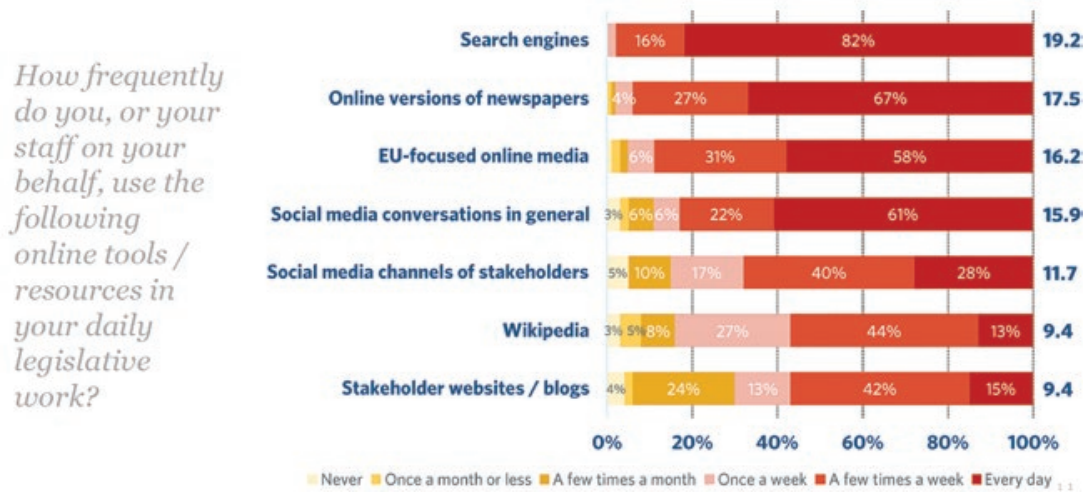

Graph 5.1 Search engines, newspapers, and EU and social media essential to legislative work. (Source: FleishmanHillard (2015): 3rd European Parliament Digital Trends Survey online, Brussels) 


\section{LobBying In the EUROPEAN UNiON}

The European Union has become a body in which the participation of lobbies has acquired significant relevance due to the generation of European regulations that directly and indirectly affect national policies. One consequence is the profusion of interest groups from European countries, but also from outside Europe, which try to influence the EU legislative process.

In order to regulate stakeholder participation, the Transparency Register was created. In 2011, both the European Parliament and the European Commission created their Transparency Register through an agreement between both institutions. This is a commitment that aims to establish a transparency framework in the relations between stakeholders and both institutions. In order to manage this Transparency Register, both the European Parliament and the European Commission created their own structure, called the Common Secretariat of the Transparency Register.

The original idea of the Transparency Register is that any organization or person whose purpose is to influence and participate in the processes and implementation of public policies of the European Union can participate in the whole process. By creating the Register, it is possible to know what kind of organizations want to participate, what interests they intend to defend or legitimize, which organizations participate in the defense of these interests and the economic and personal resources they have to carry out this representation activity. All organizations participating in the Register must adhere to a Code of Conduct. The creation of this Register allows for greater public scrutiny of the work of interest groups, as it enables the media, citizens, or any other actor in the European Union to be aware of the activities of interest groups and the influence they can have on the legislative and executive process of the European Union.

The evolution of the Transparency Register shows an upward curve, which shows the lobbies' interest in participating in EU policies (Graph 5.2).

Inclusion in the register entails a number of prerogatives for lobbyists. In the European Parliament, the advantages include access to the premises, speaking at public hearings of its committees, receiving notifications about committee activities, co-organizing events with Parliament's parties, among others. In the case of the Commission, you can have meetings with Commissioners, members of Cabinets and Directors-General; public 


\section{0}

12000

10000

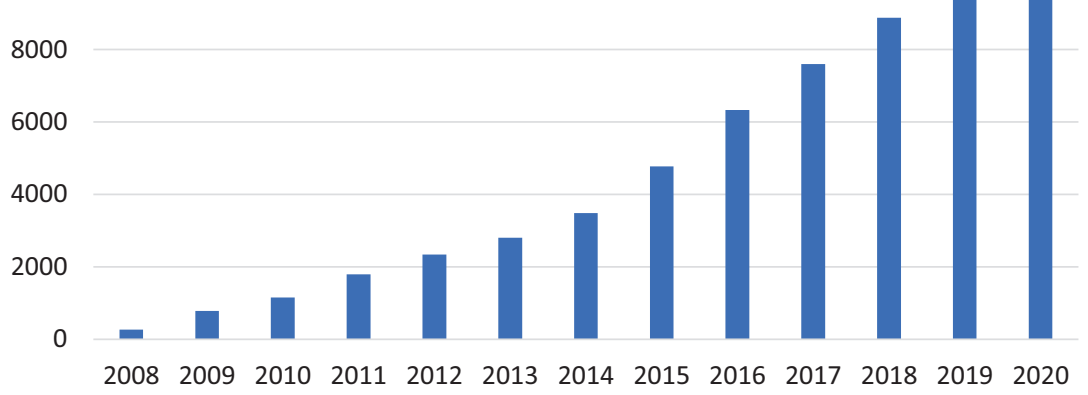

Graph 5.2 Evolution of the number of lobbies in the EU. (Source: Transparency Register (2020). Chart created for this study)

consultations (you receive automatic notification of consultations and roadmaps in the areas you have indicated); expert group (Register registration is required for the appointment of certain types of expert group members); contacts with officials, for a meeting or an event.

As an example of the transparency policy of the European Union and the importance it has for citizens and its own institutions, the Registry Secretariat offers information courses on how the Register works and the most relevant aspects of interest groups. Thus, within the European Parliament, 16 training sessions were held in 2019 for the Parliament's own staff with the title "Who are interest representatives? Introduction to the Transparency Register". Similarly, the European Commission has organized four training courses in 2019 for its own staff, under the title Dealing appropriately and effectively with interest representatives.

There have been numerous attempts to bring clarity to the actions of lobbies and recurring initiatives by the European institutions themselves or by independent bodies, such as Transparency International, which has carried out studies on the role of lobbies, as in the case of its 2015 report, entitled Lobbying in Europe: Hidden Influence, Privileged Access, in which it calls for a series of initiatives: 
(a) Require public institutions and representatives to proactively record and publish information on their interactions with lobbyists, including summaries of meetings, calendars, agendas, and documentation received.

(b) Ensure that a "legislative footprint" is created for each proposal, in order to ensure full transparency of decision-making processes.

(c) Ensure that records apply to both direct and indirect lobbying efforts, targeting all institutions and individuals who play a role in public decisions.

(d) Introduce a legal obligation for public authorities to strive for a balanced composition of advisory and expert bodies, representing a diversity of interests and views.

(e) Hold open calls to constitute the advisory/expert groups and ensure that common selection criteria are used to balance different interests.

(f) Publish legislative footprints to track, in a uniform manner, contacts and input received on draft policies, laws, and amendments.

(g) Ensure greater transparency on the composition and activities of expert groups by publishing information on the selection process of members, as well as the publication of detailed meeting minutes.

The European institutions have produced initiatives to improve transparency for the lobbying work, which are based on two main principles:

1. The legislative footprint as a mechanism that focuses on the traceability of committee legislation in Parliament and consists of a mechanism in which it is possible to observe how a piece of legislation has been modified throughout the process and who has made these contributions. This mechanism provides clarity on the actors involved, how participation has taken place and the degree of cocreation in the policy decision.

2. The publication of public agendas makes it possible to know with whom official meetings are held by the members of the commission, an element that is already in place. In addition, some recommendations extend the mere listing of meetings to include information on the topics discussed, the documentation provided, and any agreements adopted through a meetings summary. The Commission has established that its members must make public information on the meetings they and members of their cabinets hold with lobbyists, 
Professional consultancies/law firms/selfemployed consultants In-house lobbiyist and trade/business/professional associations Non-governmental organisations

Think tanks, research and academic institutions Organisations representing churches and religious communities

Organisations representing local and regional authorities, other public or mixes entities, etc.

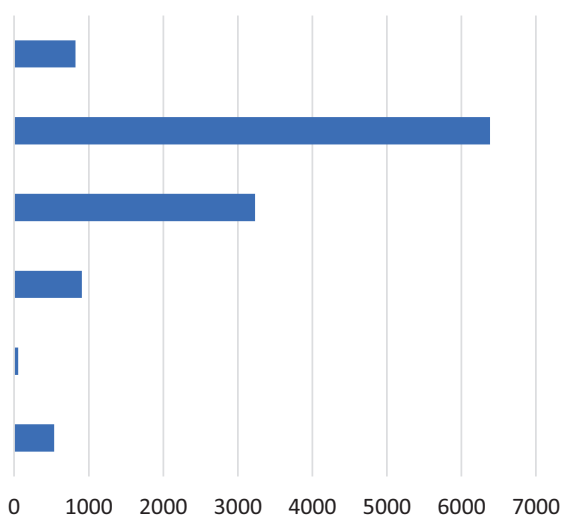

Graph 5.3 Typology of interest groups in the European Union. (Source: Transparency Register (2020). Chart created for this study)

providing information on the date of the meeting, the place where it is held, the name of the member of the Commission and/or cabinet member, the name of the organization or freelancer and the purpose of the meeting (Decision of 25 November 2014 on meetings held between members of the Commission and lobbyists) (Graph 5.3).

There are large differences in the number of lobbyists by sector. Undoubtedly, the largest group is in-house lobbyist and trade/business and professional association lobbyist, followed by nongovernmental organizations lobbyist. On the other hand, the smallest group is that of organizations lobbyist representing churches and religious communities (Graph 5.4).

Germany, France, and the UK (in the lead) together with the USA, the Netherlands, Italy, and Switzerland are the countries with the highest number of representatives. Spain, along with Denmark, Austria, Sweden, Finland, Ireland, Luxembourg, Norway, and Poland are at the other end of the spectrum (Graph 5.5).

To communicate, stakeholders mainly resort to one-on-one meetings, which are used very frequently. Stakeholder websites, issues-specific websites, and infographics are used with some frequency. Events, issues-specific websites, and sponsored media are used the least. 


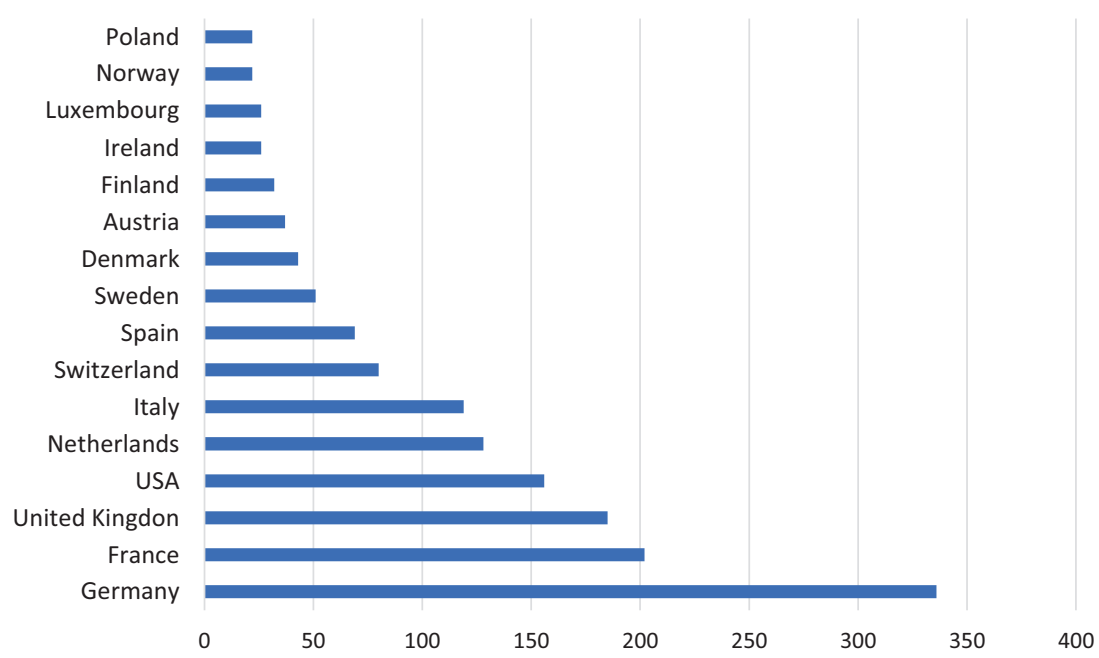

Graph 5.4 Countries with an office in Brussels. (Source: Transparency Register (2020). Chart created for this study)

\section{MEPS COUNT ON A WIDE RANGE OF CHANNELS WHEN FORMING OPINIONS ON POLICY}

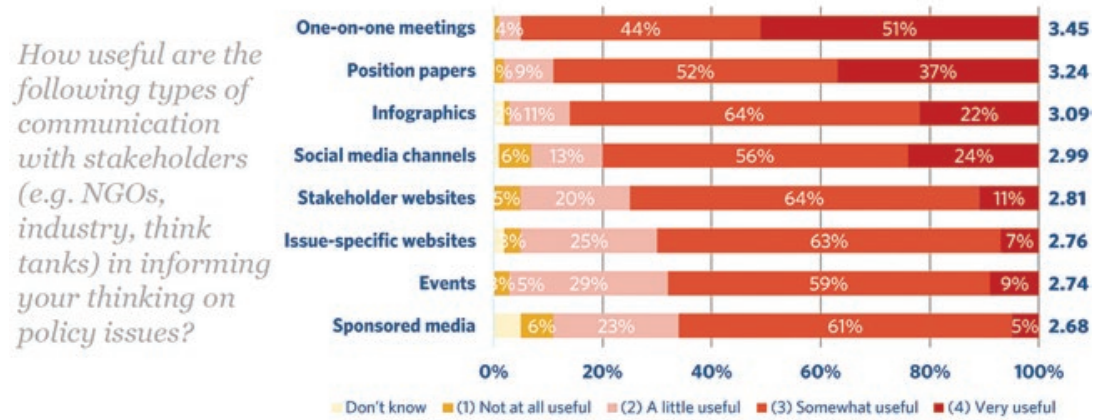

Graph 5.5 MEPs count on a wide range of channels when forming opinions on policy. (Source: FleishmanHillard (2015): 3rd European Parliament Digital Trends Survey online, Brussels) 
All contemporary political society is a system composed of many relationships and processes of power, in which individuals do no longer play the main supporting role, but in its place there is rather a multitude of associations that measure its strength according to the controlled instruments, its social presence, to the purposes advocated and to the media of influence possessed, among others. These groups have become truly important political actors in developing one continuous action toward the whole society, in general, and toward public authorities, in particular.

\section{Epilogue}

The relevance attached to groups of interest or to pressure groups (according to the field of its activity) is beyond question in the actual society, just like the mechanisms to channel the demands generated in society and aimed at public authorities, with the intention of implementing and executing the appropriate decisions in favor of and according to the interests of the groups.

The pluralist societies demonstrate the collective management of conflicts through the interactions and mutual influence among the groups present in the community. This inter-associative relevance causes that proposals have to be negotiated mutually together with the continuous contributions from, to, and over each other. Nevertheless, the fact that this configuring structure shows some hierarchical imbalances, with the presence of some groups that possess some more capacity than others to postulate or to enforce its own proposals, should not be ignored.

Pressure groups develop and implement their activities on the organizations and institutions regarded as legitimate representative bodies of popular sovereignty, and similarly there are the three classic branches of state power: Executive, Legislative, and Judicial. Similarly, they also impact significantly and increasingly, on the individuals and social groups, through action on the mass media, due to the fact that they possess a remarkable significance in shaping behaviors, attitudes, and thoughts circulating in society.

The limited social performance of associations in the social, political, and economic dynamics restricts significantly its incidence. One of the elements applied by the pressure groups in the plentiful manner consists of an appeal to the media system in order to spread the demands and groups' petitions within society. Thus, the mass media have been informed by the particular configuration in symbolic, cognitive, and informative structuring as the 
receiving instances of various types of associative activities in order to adapt its editorial space to coalition goals.

The pressure groups need the media intermediation as one more mechanism in its global strategy of pressure on the public decision-makers. Owning and gaining access to a favorable and frequent presence in media conveys the feeling and perception of a large social support to the demands and claims of groups, arousing the focus of the social concerns on those issues, which are conducive to group requirements.

Thus, communication exerted by groups or companies is an important way of generating public opinion, either directly influencing the audience or trying to influence it in a more indirect way, presenting content on events and situations that concern the group in the media.

Hence, the mass media gather, interpret, assess and transmit information proceeding from social organizations as an expression of societal ecosystem needs. Similarly, through the information system, among other mechanisms, the political system perceives the petitions of society as being capable of reaching a solution.

Resorting to mass media allows the groups to reflect its demands publicly, with the consequent political existence, due to the fact that the policy is manifested increasingly as a symbolic struggle in which each association pursues to monopolize its views successfully and to promote new claims, these being the proceedings that contribute to the achievement of group's goals.

\section{REFERENCES}

Almond, G. A. (1958). A research note: Comparative study of interest groups and the political process. American Political Science Review, 52(2), 270-282.

Almond, G. A., \& Powell, G. B. (1972). Politica comparada. Editorial Paidos.

Bentley, A. F. (1983). Il Processo di Governo. Uno studio delle Pressione Sociali. Giuffrè.

Berry, J. (1977). Lobbying for the people. The political behavior of public interest groups. Princeton University Press.

Berry, J. (1989). The interest group society. Scott Foresman/Little.

Biliouri, D. (1999). Environmental NGOs in Brussels: How powerful are their lobbying activities? Environmental Politics, 8(2), 173-182. https://doi. org/10.1080/09644019908414472

Branton, R., Martínez-Ebers, V., Carey, T. E., Jr., \& Matsubayashi, T. (2015). Social protest and policy attitudes: The case of the 2006 immigrant rallies. 
American Journal of Political Science, 59(2), 390-402. https://doi. org/10.1111/ajps.12159

Burdeau, G. (1982). Traité de Science Politique, Tom III (La Dynamique Politique), Vol. I (Les Forces Politiques). Librairie Génerale de Droit et Jurisprudence.

Carty, V. (2010). New information communication technologies and grassroots mobilization. Information. Communications Society, 13(2), 155-173. https:// doi.org/10.1080/13691180902915658

Chalmers, A. W., \& Macedo, F. S. (2020). Does it pay to lobby? Examining the link between firm lobbying and firm profitability in the European Union. Journal of European Public Policy. https://doi.org/10.1080/1350176 3.2020 .1824012

Chari, R., \& Hillebrand O'Donovan, D. (2011). Lobbying the European Commission: Open or secret? Socialism and Democracy, 25(2), 104-124. https://doi.org/10.1080/08854300.2011.579475

De Bruycker, I. (2016). Pressure and expertise: Explaining the information supply of interest groups in EU legislative lobbying. JCMS: Journal of Common Market Studies, 54(3), 599-616.

De Bruycker, I., \& Beyers, J. (2019). Lobbying strategies and success: Inside and outside lobbying in European Union legislative politics. European Political Science Review, 11(1), 57-74.

Dempsey, S. E. (2009). NGOs, communicative labor, and the work of grassroots representation. Communication and Critical/Cultural Studies, 6(4), 328-345. https://doi.org/10.1080/14791420903348625

Dür, A. (2008). Measuring interest group influence in the EU: A note on methodology. European Union Politics, 9(4), 559-576.

Dür, A., Bernhagen, P., \& Marshall, D. (2015). Interest group success in the European Union: When (and why) does business lose? Comparative Political Studies, 48(8), 951-983. https://doi.org/10.1177/0010414014565890

Easton, D. (1965). Esquema para el análisis político. Amorrortu Editores.

Fowler, L. L., \& Shaiko, R. G. (1987). The grass roots connection: Environmental activists and senate roll calls. American Journal of Political Science, $31(3), 484-510$.

Gallagher Cunningham, K., Dahl, M., \& Frugé, A. (2017). Strategies of resistance: Diversification and diffusion. American Journal of Political Science, 61(3), 591-605. https://doi.org/10.1111/ajps.12304

Grant, W. (1989). Pressure groups, politics and democracy. Philip Allan.

Gray, V., \& Lowery, D. (1993). The diversity of state interest group systems. Political Research Quarterly, 46(1), 81-98.

Hrebenar, R. J., \& Scott, R. K. (1990). Interest groups politics in America. Prentice Hall.

Klüver, H. (2013). Lobbying in the European Union: Interest groups, lobbying coalitions and policy change. Oxford University Press. 
Klüver, H., Braun, C., \& Beyers, J. (2015). Legislative lobbying in context: Towards a conceptual framework of interest group lobbying in the European Union. Journal of European Public Policy, 22(4), 447-461. https://doi.org/1 $0.1080 / 13501763.2015 .1008792$

Lowery, D. (2013). Lobbying influence: Meaning, measurement and missing. Interest Groups \& Advocacy, 2(1), 1-26.

Marshall, D. (2015). Explaining interest group interactions with party group members in the European Parliament: Dominant party groups and coalition formation. JCMS: Journal of Common Market Studies, 53(2), 311-329.

McFarland, A. S. (1987). Los grupos de presión en el Congreso norteamericano. Gernika.

Mergeai, S., \& Gilain, H. (2020). Analyse comparative des stratégies employées par le lobby pharmaceutique, gazier et automobile visant à influencer les réglementations de l'UE. Louvain School of Management, Université Catholique de Louvain.

Meynaud, J. (1962). Nouvelles études sur les groupes de pression en France. Armand Colin.

Rasmussen, A. (2015). Participation in written government consultations in Denmark and the UK: System and actor-level effects. Government and Opposition, 50(2), 271-299.

Rasmussen, A., Mader, L. K., \& Reher, S. (2018). With a little help from the people? The role of public opinion in advocacy success. Comparative Political Studies, 51(2), 139-164.

Schnakenberg, K. E. (2017). Informational lobbying and legislative voting. American Journal of Political Science, 61(1), 129-145. https://doi. org/10.1111/ajps.12249

Whiteley, P. F., \& Winyard, S. J. (1987). Pressure for the poor. The poverty lobby and policy makings. Methuen.

Ziegler, H., \& Dye, T. R. (1990). The irony of democracy. An uncommon introduction to American politics. Cole Publishing Company. 